\title{
Rozwój samogłosek nosowych w gwarze strzepskiej
}

Słowa klucze: język kaszubski; gwary kaszubskie; fonetyka; fonologia; samogłoski nosowe

Ke yw o rd s: Kashubian language; Kashubian dialects; phonetics; phonology; nasal vowels

\section{Wstęp}

Niezwykłą dynamikę w zakresie wymowy pierwotnych samogłosek nosowych - zarówno pod względem barwy ustnej, jak i charakteru nosowości obserwować możemy już w najstarszych naukowych opisach kaszubszczyzny. Wymienić tu można choćby prace Aleksandra Hilferdinga (Гильфердинг 1862: 84-85) i Leona Biskupskiego (Biskupski 1883: 6, 12-17, 19-20, 38-39, 50-56). Znaczne zróżnicowanie pomiędzy poszczególnymi gwarami, ale również rozchwianie w obrębie jednego i tego samego punktu terenowego w połowie XX wieku poświadcza monograficzne opracowanie autorstwa Aliny Ściebory (Ściebora 1973). Aktualne opracowania poszczególnych gwar i obszarów dialektalnych wskazują na dalsze, bardzo intensywne zmiany w ostatnim półwieczu (Jocz 2013; 2014; 2015a; 2015b; 2016a, 2016b). 
Celem niniejszego artykułu jest analiza współczesnej wymowy i statusu fonologicznego pierwotnych samogłosek nosowych w gwarze strzepskiej. Gwara ta jest pod względem rozwoju nosówek szczególnie ciekawa. Leży ona bowiem pomiędzy ogniskami dwóch silnych, przeciwstawnych zjawisk: północnokaszubskiej tendencji do konsonantyzacji nosowości i centralnokaszubskiej do denazalizacji. Wspomnieć tu należy, że sąsiadująca z gwarą strzepską od północy gwara luzińska przyjęła w ciągu ostatnich kilkudziesięciu lat wymowę północnokaszubską (Jocz 2016a; 2016b).

Materiał badawczy stanowią cztery nagrania wykonane w maju 2016 r. Informatorami były cztery osoby: kobieta i mężczyzna w wieku średnim (odpowiednio K1 i M1) oraz kobieta i mężczyzna w wieku starszym (odpowiednio K2 i M2) ${ }^{1}$. Wszystkie te osoby wychowały się w Strzepczu, ich rodzice pochodzili również z tej wsi lub z najbliższej okolicy. Wywiady polegały na tłumaczeniu zdań z języka polskiego na miejscową gwarę. Zdania zaczerpnięto z artykułów Zuzanny Topolińskiej, opisujących systemy fonologiczne południowo-, centralno- i północnokaszubskie (Topolińska 1967a; 1967b; 1969). Czas trwania pojedynczego nagrania wyniósł ok. 20 minut, na odpowiedzi informatora przypadła w przybliżeniu połowa tego czasu. Zważywszy na to, iż rzeczone zdania przygotowane zostały specjalnie do badań nad gwarowym zróżnicowaniem kaszubszczyzny, taka objętość materiału pozwala na wyciągnięcie wniosków o znacznym stopniu szczegółowości i pewności.

Łącznie w nagraniach pierwotne samogłoski nosowe powinny były wystąpić niemal 500 razy. Ostatecznie wziąłem pod uwagę 469 realizacji (123 od K1, 110 od M1, 127 od K2 i 109 od M2), w tym 125 wymówień *[ã] w śródgłosie i 145 w wygłosie oraz 72 wymówienia *[õ] w śródgłosie i 127 w wygłosie. Części poświadczeń nie uwzględniłem ze względu na potknięcia artykulacyjne w obrębie słowa lub redukcje, uniemożliwiające interpretację cech interesujących nas głosek, np. ['dobr] 'dobrą', [mæm] 'mają',

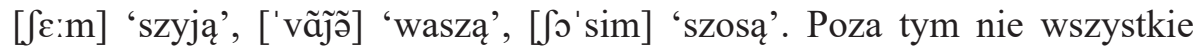
zdania przetłumaczone zostały przez wszystkich informatorów w ogóle czy w ten sam, oczekiwany sposób. Dodatkowo wynotowałem 33 poświadczenia połączeń [aN] w śródgłosie i wygłosie oraz 49 wymówienia wygłosowego *[cm] (w końcówce narzędnika).

1 Dla uproszczenia będę w dalszej części pracy stosował określenia pokolenie młodsze, informatorzy młodsi, pokolenie starsze, informatorzy starsi itp. 
Podstawą wniosków przedstawionych w niniejszym artykule były analizy audytywne (w każdym przypadku przesłuchiwałem co najmniej kilkukrotnie całe wyrazy, poszczególne segmenty i ich części) połączone każdorazowo $\mathrm{z}$ wnikliwą wzrokową analizą spektrogramów (w razie potrzeby dokonywałem również pomocniczych pomiarów). Produktem pośrednim była prosta baza danych, w której każde poświadczenie zostało oznaczone co do etymologicznej nosówki (lub połączenia [VN]), informatora, pozycji w obrębie słowa fonetycznego, miejsca i sposobu artykulacji następującej spółgłoski, barwy ustnej, nosowości całego segmentu samogłoskowego, obecności rozszczepienia $\mathrm{z}$ asymilacją i bez asymilacji ${ }^{2}$, wymowy nosowości $\mathrm{w}$ formie glajdu ${ }^{3} \mathrm{i}$ barwy tego glajdu, wymowy z częściową nosowością segmentu wokalicznego, rozłożenia na [Vm] w wygłosie oraz całkowitej denazalizacji. Ostatnią pozycją była kompletna transkrypcja słowa, zawierającego dane poświadczenie.

Podawanych w niniejszym opracowaniu danych liczbowych nie należy oczywiście $z$ różnych względów absolutyzować. Po pierwsze trzeba mieć na uwadze, że chodzi tu o sytuację w konkretnym i ograniczonym materiale. Informacja, że taka czy inna wymowa wystąpiła np. w 0,5\%, 40\% lub 70\% przypadków, nie ma sugerować, że są to jakieś stałe częstotliwości panujące w gwarze. Szczególnie dotyczy to izolowanych poświadczeń. Celem w takich przypadkach jest tylko i wyłącznie ukazanie ogólnych stosunków wymowy w czytelny sposób. Oczywiście w przypadku bardziej szczegółowych rozważań (i niższych dzielników, ale zazwyczaj i tak wyższych od 20) podawane wartości są bardziej orientacyjne niż w przypadku rozważań bardziej ogólnych (i wyższych dzielników, wyraźnie przekraczających 100), gdzie liczebność próbki pozwala już na zdecydowane wnioski. Po drugie uwzględnić należy niewielką liczbę informatorów, choć z moich doświadczeń na Kaszubach wynika, że czterej zróżnicowani wiekowo informatorzy na punkt terenowy pozwalają na bardzo dobry wgląd w jego system dźwiękowy ${ }^{4}$. Zresztą z podobnymi liczbami informatorów mamy do czynienia w wielu

2 Tak określam typ wymowy ze spółgłoską nosową zgodną co do miejsca artykulacji z następującą spółgłoską (np. ['zambe]) i odpowiednio bez takiej zgodności (np. 'zajbe]).

${ }^{3}$ Chodzi tu o wymowę typu [gaũs], odpowiadającą również polskiej wymowie literackiej w pozycji przed szczelinowymi.

${ }^{4}$ Zwrócić tu należy uwagę, że w przebadanym materiale zarejestrowałem w zależności od głoski i pozycji wszystkie lub niemal wszystkie możliwe typy wymowy. 
dotychczasowych opracowaniach kaszubszczyzny, m.in. w najważniejszym tu dla nas opracowaniu Ściebory (1973). Niemniej jednak można z tych powodów traktować niniejszy opis w pewnej mierze jako wstępny.

W niniejszym artykule używam standardowej transkrypcji IPA. Koniecznych jest tu kilka drobnych uwag. Litery [s, $\left.z_{\imath}, t s, d z\right]$ odpowiadają polskim $s z, \dot{z}, c z, d \dot{z}$, znaki $\left[\int, 3, \mathrm{t} \int, \mathrm{d} 3\right]$ symbolizują zaś spółgłoski mniej lub bardziej wyraźnie zmiękczone. Afrykaty oznaczam za pomocą kombinacji typu [ts], w przypadku połączeń zwartej ze szczelinową używam natomiast zapisu [t-s]. Taki sam sposób notacji stosuję do rozróżniania dyftongów od połączeń dwóch samogłosek. Symbol [ọ] reprezentuje dźwięk tożsamy z polskim $y$. Litery [a] używam na oznaczenie samogłoski przednio-centralnej i przedniej, dla wymowy bardziej tylnej (choć nie tylko stricte tylnej) stosuję symbol [a]. W razie znaczniejszej sprzeczności obecnej wymowy z zastosowanym oznaczeniem będę stosował gwiazdkę (np. */e/). Zapis typu */e/ oznacza nie tylko brzmienie rekonstruowane, stosuję je również jako synonim sformułowania „kontynuant(y) */e/”, „fonem kontynuujący */e/” itp.

Dysponujemy dwoma precyzyjnymi opisami wymowy samogłosek nosowych w interesującej nas gwarze przed kilkudziesięcioma laty. Pierwszym z nich jest Atlas Językowy Kaszubszczyzny... (AJK 1964-1978), drugim zaś wspomniana już powyżej monografia Ściebory (1973). Zanim przejdę do analizy własnych danych, przedstawię pokrótce obraz wyłaniający się z tych opracowań.

W AJK gwara strzepska reprezentowana jest przez Strzepcz, Zęblewo i Niepoczołowice. Ogólnie rzecz biorąc, * *ã ] w śródgłosie ma się tu charakteryzować barwą [a] i wymową synchroniczną. Szczególnie konsekwentny wydaje się być tu Strzepcz, w pozostałych, peryferyjnych punktach udokumentowane są natomiast w części przykładów zarówno inne barwy $([\varepsilon, æ, \supset, \mathrm{p}])$, jak i inne kontynuanty nosowości (obok nosowości synchronicznej występuje tu też rozszczepienie z asymilacją bez zachowania nosowości segmentu wokalicznego lub z nim). *[õ] w zależności od przykładu przyjmuje we wszystkich punktach to barwę [u], to [o] bez żadnej zasady. Nosowość jest w śródgłosie zasadniczo synchroniczna, choć znów tylko Strzepcz jest tu konsekwentny. W pozostałych dwóch miejscowościach udokumentowane są natomiast również obie formy rozszczepienia $z$ asymilacją. Jeżeli chodzi o pozycję wygłosową, to w przypadku *[ã] zachowanie nosowości na całym obszarze konkuruje z denazalizacją, przy czym odnosowienie w Strzepczu 
jest rzadkie, a w Zęblewie i Niepoczołowicach nieco częstsze. *[õ] w wygłosie zachowuje na interesującym nas obszarze synchroniczną nosowość, ulega denazalizacji lub rozszczepieniu na połączenia [Vm]. Najbardziej archaiczna wymowa charakteryzuje znowu Strzepcz (AJK 13: 169-197, mapy 624-634, mapy syntetyczne 1-4).

W opracowaniu Ściebory naszą gwarę reprezentują tylko dwa punkty, Zęblewo i Niepoczołowice. Niestety brak tu samego Strzepcza. *[ã] przed zwartymi zachowuje nosowość bardzo dobrze zarówno u starszego, jak i młodszego pokolenia, choć udział takich wymówień w tej drugiej grupie jest zauważalnie mniejszy. Niemniej jednak u większości informatorów przekracza on bardzo wyraźnie poziom 50\% (najniższa wartość to 41\%). Nierzadkie jest rozszczepienie (w zależności od punktu dominuje tu forma z zachowaniem nosowości segmentu wokalicznego lub jej brakiem). Denazalizacja jest ogólnie rzadka, tylko u jednego informatora osiąga 9\% (Ściebora 1973: 34-40, 50-55). Jeżeli chodzi o *[õ] przed zwartą, to Ściebora obserwuje brak głównego typu wymowy i duże zróżnicowanie indywidualne. W pokoleniu starszym udział wymowy synchronicznej jest jednak nadal znaczny (ok. 40-55\%). W Zęblewie takie realizacje konkurują z rozszczepionymi, w Niepoczołowicach nierzadka jest oprócz tego denazalizacja $(19,4 \%)$. W pokoleniu młodszym tendencja do rozszczepienia ogólnie nasila się (udział wymówień tego typu osiąga w zależności od informatora ok. 30-80\%), choć indywidualnie nosowość synchroniczna może być nadal bardzo częsta (do 44\%). Zauważalny jest również pewne nasilenie odnosowienia w Niepoczołowicach (ok. 23-30\%) (Ściebora 1973: 74, 79-80, 91-94). Dla pozycji przed szczelinową Ściebora podaje tylko ogólne informacje statystyczne. *[ã] charakteryzować się ma w mowie pokolenia starszego wymową synchroniczną w $82 \%$ przypadków. Pozostałe $18 \%$ przypada głównie na realizacje odnosowione, pozostałe typy wymowy są sporadyczne. U młodszych informatorów nosowość synchroniczna okazała się nawet nieco częstsza $(87,4 \%)$, inne typy wymowy badaczka zarejestrowała tu rzadko lub wręcz wyjątkowo (Ściebora 1973: 99-102). Również w przypadku *[õ] u obu pokoleń absolutnie dominują realizacje synchroniczne, a pozostałe sposoby wymowy są rzadkie (Ściebora 1973: 104-106). Nosowość w wygłosie ma być na interesującym nas terenie zachowana ogólnie bardzo dobrze. W przypadku wygłosowego $*[\tilde{a}]$ pewną rolę odgrywa czynnik morfologiczny. W końcówkach imiennych starsi informatorzy zachowywali no- 
sowość w 61,7\% przypadków, a do denazalizacji doszło w 35\% realizacji. U osób młodszych liczby te wyniosły odpowiednio 38,8\% i 60\%. W przypadku końcówek czasownikowych różnica międzypokoleniowa okazała się o wiele mniejsza. W pokoleniu starszym nosowością synchroniczną charakteryzowało się 81,5\% wymówień, a odnosowieniem - 15,8\%. W mowie młodszych informatorów wartości to $66,5 \%$ i $32 \%$. Pozostałe sposoby wymowy (konsonantyzacja, wymowa wyraźnie glajdowa ${ }^{5}$ ) okazały się sporadyczne. Jeżeli chodzi o *[õ], to nosowość synchroniczna w obu pokoleniach zachowana byłą w 55-60\% przypadków. Udział denazalizacji to ok 14-20\%. Częste było tu również rozszczepienie na [Vm] (18\%-27\%). Co ciekawe, indywidualnie dość częsta była wymowa wyraźnie glajdowa $(1,8-10,4 \%)$ (Ściebora 1973: 148-152). Typową barwą *[ã] w materiale Ściebory jest ogólnie [a]. Nierzadkie (i występujące w pewnej mierze zależnie od punktu terenowego i informatora) są jednak również barwy $[\varepsilon, æ, \diamond, p]$. Ich udział może dochodzić do ok 10-20\% (Ściebora 1973: 124-130). Najczęstszymi barwami $*[\widetilde{o}]$ było natomiast $[\mathrm{o}, \mathrm{u}](\mathrm{z}$ tendencją do wymowy $[\mathrm{u}])$, wcale nierzadkie było też [o] (Ściebora 1973: 141-142).

Ogólnie rzecz biorąc, dotychczasowe opisy pouczają nas, że kilkadziesiąt lat temu na interesującym nas obszarze dobrze lub wręcz bardzo dobrze utrzymywała się synchroniczna wymowa pierwotnych samogłosek nosowych ${ }^{6}$. Niemniej jednak tendencja do innych rodzajów wymowy (głownie chodzi tu o rozszczepienie przed zwartymi, ale też denazalizację w różnych pozycjach) już wówczas była bardzo wyraźna.

5 Co do znaczenia tego określenia por. przypis 5.

${ }^{6}$ Otwartą kwestią pozostaje, co tak naprawdę autorzy tych opisów rozumieli pod pojęciem wymowy synchronicznej. W opracowaniach polonistycznych nagminnie wręcz określa się bowiem tym mianem wymowę glajdową typu kęs [keũs], która w swej istocie jest jednak równie asynchroniczna, jak wymowa rozszczepiona typu zęby ['zembэ̣]. Ściebora wyróżnia co prawda obok wymowy synchronicznej jeszcze jeden rodzaj wymowy „wokalicznej”, którego opis sugeruje, że chodzi tu o realizacje z jakimś glajdem. Mam jednak poważne wątpliwości, czy mamy tu naprawdę do czynienia z przeciwsta-

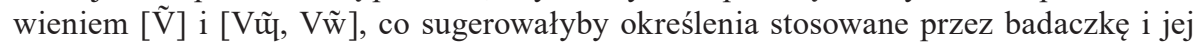
opisy artykulacyjne. Wysoce prawdopodobne jest według mnie, że chodziło tu w rzeczywistości o różnicę pomiędzy wymowami o różnym stopniu napięcia czy różnej barwie glajdu (np. [Vũ̃] wobec [Vw̃u]). W stosunku do rodzaju nosowości, oznaczanego przez Ścieborę za pomocą symbolu stosuję określenie nosowość wyraźnie glajdowa. 


\section{2. *[ã] w śródgłosie}

Rozpocznijmy od kontynuantów nosowości w pozycji przed zwartą $^{7}$ (wykresy 1-3). Pomiędzy przedstawicielami pokolenia starszego brak jednolitości. U informatorki K2 we wszystkich przypadkach dochodzi do rozszczepienia z asymilacją. W 83\% przypadków segment samogłoskowy jest przy tym całkowicie odnosowiony (np. [pwэdzay'kwevats] 'podziękować', ['rajka] 'rękę', ['pjanknọ] 'piękny', [gwam'bwekŭm] 'głęboką', ['stconka] 'szczęka', ['zamb3] 'zęby', ['dp̣mbuf] 'dębów', ['pjjantș] 'pięć', ['xantno] 'chętnie', ['zaŏnts] 'zięć'). W pozostałych 17\% poświadczeń spółgłosce nosowej towarzyszy albo glajd, albo częściowa nosowość samogłoski (['saũgkuf] 'sęków', ['vñ̃ygle] 'węgla', ['pjjaãnta] 'pięta'). U informatora M2 wymówienia z rozszczepieniem stanowią tylko 31,6\% wszystkich, przy czym w większości $(66,7 \%)$ takich przypadków mamy do czynienia z całkowitą lub częściową nosowością segmentu wokalicznego (['võygla] 'węgla', ['daãmbə] 'dęby', ['gwaõmbøk] 'głęboko', ['xaãntnę] 'chętnie' obok [pusdzan' kwevats] 'podziękować', [gwom 'bwekọ] 'głęboka'). Na poświadczenia bez wyodrębnienia spółgłoski nosowej (czyli pozostałe 68,4\%) u tego informatora składa się 57,9\% realizacji dyftongicznych (np. ['raw̃ka] 'rękę', ['raũkvof] 'rąk', ['saũ kuf] 'sęków', ['daũ bof] 'dębów', ['pjaũta] 'pięta', ['mijaũutkọ] 'miękka', [zaũts] 'zięć') i 10,5\% realizacji z nosowością końcowej fazy artykulacji samogłoskowej (['zaõ̃b3] 'zęby', ['rã̃tse] 'ręce'). Informator M2 charakteryzuje się więc wymową bardziej archaiczną (jest to najprawdopodobniej specyfika indywidualna, niezwiązana ściśle i bezpośrednio z innymi czynnikami socjolingwistycznymi). Niemniej jednak u żadnego z informatorów starszych nie stwierdziłem ani razu wymowy synchronicznej. Nawet w przypadku nosowości glajdowej i wokalicznej mamy do czynienia z oczywistą asynchronią.

Informatorzy młodsi są pod względem wymowy przed zwartymi całkowicie jednolici. We wszystkich poświadczeniach doszło do rozszczepienia z asymilacją. W przeważającej większości przypadków (95\%) segment wokaliczny jest całkowicie odnosowiony (['ranka] 'ręka', ['pijajknọ] 'piękny', ['sankuf] 'sęków', ['vangla] 'węgla', [podzen'kwwovats] 'podziękować', [gwam'bwekọ] 'głęboka', ['zambę] 'zęby', ['dambuf] 'dębów', ['pijanta]

7 Określenie to stosuję w niniejszym opisie łącznie dla zwartych i afrykat. 
'pięta', [pjjants] 'pięć', ['xantno] 'chętnie', [zants] 'zięć', ['rants3] 'ręce'), $\mathrm{w}$ pozostałych poświadczeniach $(5 \%)$ nosowością charakteryzuje się część samogłoski przyległa do spółgłoski nosowej (['ctcaẵyka] 'szczęka', ['daẵmb $\underline{\varepsilon}$ ] 'dęby'). U informatorów reprezentujących pokolenie średnie obserwujemy więc bez wyjątku wymowę progresywną.

Pomimo stwierdzonych różnic międzypokoleniowych w zgromadzonym materiale nie zanotowałem $\mathrm{u}$ *[ã] przed spółgłoskami zwartymi ani razu wymowy synchronicznej. Stanowi to wyraźną różnicę w stosunku do starszych opracowań.

Przejdźmy do pozycji przed szczelinową (wykresy 4-6). U informatorów starszych w 92,4\% poświadczeń zachowana jest tu nosowość, przy czym we wszystkich przypadkach jest to nosowość glajdowa z całkowitym odnosowieniem segmentu samogłoskowego (np. ['mjjaũuso] 'mięso', ['jaũzộ] 'ję̨-

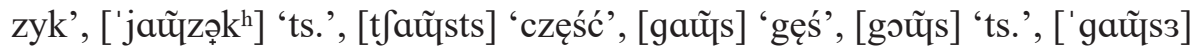
'gęsi', ['t6oũ ftci] 'ciężki', ['t6aũftci] 'ts.'). W 7,6\% przypadków doszło do denazalizacji (['mjjaeso] 'mięso', ['mijaes@] 'ts.'), choć pierwotna nosowość pozostawiła tu wyraźny ślad w wymowie segmentu samogłoskowego (patrz niżej). Zachowaniu nosowości (jak zresztą i denazalizacji) towarzyszy więc wymowa wyraźnie asynchroniczna.

Pomiędzy informatorami młodszymi wystąpiły zauważalne różnice. Informatorka $\mathrm{K} 1 \mathrm{w}$ 84,6\% wymówień zachowuje nosowość, przy czym zawsze jest to nosowość o charakterze asynchronicznym, zazwyczaj wyraźnie glajdowym, rzadziej samogłoskowym. W 9,1\% przypadków z zachowaną nosowością glajdowi towarzyszy nosowość całego segmentu samogłoskowego, w 27,3\% nosowość jego przyległej części, w 63,6\% poświadczeń natomiast obserwujemy całkowitą denazalizację segmentu samogłoskowego (['tøã̃̃ctci] 'ciężki' obok ['mijaãũuso] 'mięso', [gaãũus] 'gęś', ['jaãũuzọk]

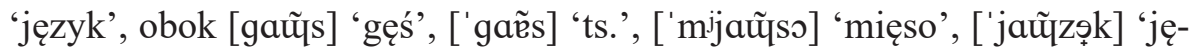
zyk', [vaũx] 'węch', ['tcaẽsts] 'część'). Wymowy z pełną denazalizacją mają u tej osoby udział 15,4\% (['mijaess] 'mięso', ['mijaeso] 'ts.'). U informatora M1 wymówienia z zachowaną nosowością stanowią tylko 27,3\% wszystkich poświadczeń, przy czym mamy tu zawsze wymowę glajdową z pełną denazalizacją segmentu samogłoskowego (['t faũ ftji] 'ciężki', ['jaũzộk] 'ts.', ['jaũzộk] 'język'). Pozostałe 72,7\% przypadków charakteryzuje się całkowitym odnosowieniem (np. [gaes] 'gęś', ['mjaess] 'mięso', 
['tfarsts] 'część'). Również pokolenie młodsze - wbrew dotychczasowym opisom - charakteryzuje się więc tu wymową asynchroniczną.

Innych, niewspomnianych dotąd typów nosowości (np. konsonantyzacji przed szczelinową, rozszczepienia bez asymilacji), opisywanych jako marginalne w dotychczasowych opracowaniach, nie zaobserwowałem ani razu.

Nosowość *[ã] niezależnie od prawostronnego sąsiedztwa fonetycznego, różnic międzypokoleniowych i skłonności indywidualnych jest w przebadanym materiale zawsze wyraźnie asynchroniczna. Fonetycznie złożone są również kontynuanty odnosowione (patrz niżej). Jest to sytuacja całkowicie odmienna od przedstawianej w starszych opisach. Trudno jednoznacznie stwierdzić, na ile jest to kwestia rozwoju, a na ile odmiennej percepcji.

Ostatnią kwestią jest barwa ustna zarówno segmentu samogłoskowego (zgłoskotwórczego), jak i elementów glajdowych (niezgłoskotwórczych). Zagadnienie to omówię bez ścisłego podziału na informatorów, gdyż pomimo pewnych skłonności indywidualnych ogólny obraz jest dość jednolity. W $84 \%$ wszystkich barwa elementu zgłoskotwórczego to [a], w zasadzie centralno-tylne (np. ['saũykuf] 'sęków', ['zamb3] 'zęby', [pjants] 'pięć', ['ranka] 'ręka', ['daũbof] 'dębów'). Jedno poświadczenie $(0,8 \%)$ zawiera samogłoskę scentralizowaną ([dzzy' $\mathrm{k}^{\mathrm{h}} \mathrm{w}$ wats] 'dziękować'), zapewne mamy tu do czynienia z nieregularną redukcją poza akcentem. Żadnych innych typów wymowy (oprócz [a] i izolowanego [3]) nie stwierdziłem u najmłodszej informatorki K1. W 4\% procentach przypadków zarejestrowałem barwę typu [p] o bardzo słabej labializacji i ewentualnie lekkim wzniesieniu ${ }^{8}$ (['voñygle] 'węgla', ['dp̣mbə] 'dęby', ['dp̣mbuf] 'dębów', [gwom'bwekọ] 'głęboka', [guom' bwskọ] 'ts.'). Zwrócić należy uwagę, że w każdym z tych przypadków mamy do czynienia z przynajmniej jednostronnym sąsiedztwem spółgłoski wargowej i tylko $\mathrm{w}$ dwóch przypadkach jedną z sąsiednich głosek jest spółgłoska niemarginalna. Zapewne nie jest to przypadek. W 7,2\% poświadczeń mamy tu barwę [0] (['rojka] 'rękę', ['mjjontkg̣] 'miękka', ['võygla] 'węgla', ['tøəũ̃ftci] 'ciężki', ['mjoũuso] 'mięso', [goũs] 'gęś', ['stconka] 'szczęka', [gom'bwekọ] 'głęboka', [gwom'bwekọ] 'ts.'). Brak tu jednoznacznego uwarunkowania pozycyjnego. Barwę tę najczęściej zanotowałem u informatorki K2. Kolejną możliwością (zarejestrowaną u obu męż-

8 Pod względem zaokrąglenia samogłoska ta nieporównywalna jest do swojego odpowiednika w gwarze sierakowsko-gowidlińskiej. 
czyzn) jest wymowa dyftongiczna, gdzie [p] przechodzi w (ustne lub nosowe) [o] (['zaŏnts] 'zięć', ['raŏntsc] 'ręce', ['gwaõmbsk] 'głęboko', ['zaõos] 'zęby', ['rã̃tse] 'ręce'). Wystąpiła ona w 4\% przypadków. Również tu brak zależności od kontekstu.

Jeżeli chodzi o nosową artykulację glajdową (niezgłoskotwórczą), to najczęściej (92\%) przyjmuje ona barwę [ũ] (por. przykłady powyżej). Po 2\%

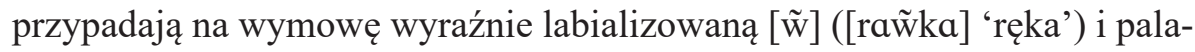
talną [ĩ] (['tcã̃ictci] 'ciężki'). Ta ostatnia związana jest z miejscem artykulacji następującej spółgłoski (podobnie jak w polszczyźnie). Dwukrotnie (4\%) pojawiła się artykulacja bardzo otwarta (['gã̃s] 'gęś', ['t6ã̃sts] 'część'), stanowiąca według mnie ogniwo pośrednie w kierunku denazalizacji.

Dokładniejszego omówienia pod względem barwy wymaga odnosowiony kontynuant *[ã], występujący przed szczelinowymi. Zastosowałem tu zapis [ae] (['mjjarso] 'mięso', ['mjarso] 'ts.', ['mjjars@] 'ts.', [gaes] 'gęś', [tfarsts] 'część'), który ma jednak w dużej mierze charakter symboliczny. Fazą początkową jest tu [a]. Faza końcowa przyjmuje barwę nieco podwyższoną i bardziej tylną oraz - przede wszystkim - charakteryzuje się wyraźnym spadkiem energii akustycznej i rozmyciem struktury formantowej (w tym zwiększeniem się szerokości formantów). Są to cechy akustyczne odpowiadające nazalizacji, w przypadku omawianej wymowy brak jednak uchwytnej audytywnie nosowości. Przy przesłuchiwaniu całych słów uwagę zwraca w pierwszym rzędzie długość wokoidu (jest on wyraźnie dłuższy od realizacji etymologicznego [a] w tej samej pozycji). Nie budzi wątpliwości również jakaś modyfikacja barwy, jest ona jednak bardzo trudna do sprecyzowania. Nierzadko przy przesłuchiwaniu całych słów wydaje się, że chodzi o lekką nosowość, ale przy analizie poszczególnych segmentów okazuje się to iluzją. Do określenia, jaki z możliwych gestów artykulacyjnych stoi za tym efektem, potrzebne byłyby instrumentalne badania artykulacyjne. Tego typu wymowa nie jest zresztą typowa wyłącznie dla Strzepcza, zaobserwowałem ją bowiem również w okolicach Kartuz. Przedstawiony przeze mnie w jednej z poprzednich prac podstawowy opis akustyczny jest adekwatny także dla interesującej nas gwary (Jocz 2014: 52-53). Można podejrzewać, że jest to jedno z ogniw pomiędzy glajdową nosowością *[ã] i wybitnie tylnymi i wyraźnie zaokrąglonymi barwami odnosowionymi typu [p], charakterystycznymi dla gwary sierakowsko-gowidlińskiej. 
Kontynuanty *[ã] są więc bez wyjątku - niezależnie od takiej czy innej realizacji w tej czy innej pozycji - fonetycznie złożone. Przed zwartymi zwycięża tendencja do rozszczepienia, konsonantyzacji. Przed szczelinowymi zaś wydaje się do głosu silniej dochodzić skłonność do odnosowienia, choć młodsi informatorzy różnią się tu wyraźnie między sobą. Niemniej jednak stan jest w wielu aspektach wyraźnie odmienny od przedstawionego w starszych opracowaniach.

\section{3. *[ãa w wygłosie}

Pod względem wymowy $*[\tilde{a}]$ w wygłosie (wykres 7) sytuacja jest zupełnie prosta i jednakowa u wszystkich informatorów. Zawsze dochodzi tu mianowicie do denazalizacji. Dotyczy to zarówno wygłosu absolutnego, jak i pozycji w sąsiedztwie jakiejkolwiek następującej głoski, niezależnie od miejsca i sposobu jej artykulacji. Nie odgrywa tu również żadnej roli czynnik morfologiczny, tzn. fakt, czy *[ã] stanowi końcówkę werbalną czy nominalną i jaką konkretnie kategorię gramatyczną reprezentuje. Dla ilustracji podam po kilka przykładów bez podziału na informatorów: ['tscla] 'cie-

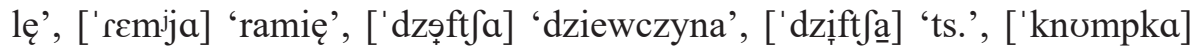
'guzik', ['rojka] 'rękę', ['gwo̦va] 'głowę', ['wuyka] 'łąkę', ['broda] 'brodę', ['sctcəra] 'siekierę', ['na $a$ a] 'naszą', [sa] 'się', ['piifa] 'piszę', ['robja] 'robię', ['jida] 'idę', ['zesska] 'skoszę', ['stoja] 'stoję', ['vidza] 'widzę', ['mufa] 'muszę'. Stan jest więc obecnie diametralnie różny od zarejestrowanego przed kilkudziesięciu laty.

Barwa wygłosowego *[ã ] jest także bardzo jednolita. W 98,6\% przypadków mamy tu do czynienia $\mathrm{z}$ [a] lub ewentualnie z substytutami mniej peryferyjnymi (typowymi również dla nieakcentowanego *[a]). Raz $(0,7 \%)$ zanotowałem barwę [ə] (['stspınə] 'ścianę'), którą przypisać należy nieregularnej, silnej redukcji. Również jednokrotnie $(0,7 \%)$ zanotowałem wymowę [॰] ([so] 'się'). Zaimek zwrotny jest jednak przypadkiem szczególnym zarówno pod względem morfologicznym, jak i fonetycznym. Poza tym niewykluczona jest kontaminacja z formą zaimkową so 'sobie', por. (Ściebora 1973: 162). Całkowita denazalizacja nie przyniosła więc zwiększenia częstotliwości wariantów odrębnych pod względem barwy od [a]. Wręcz przeciwnie, w stosunku do starszych opisów doszło tu do ujednolicenia wymowy i zaniku rzadszych odmian. 


\section{4. *[õ] w śródgłosie}

Wymowę śródgłosowego *[õ] rozpatruję ogólnie, bez podziału na poszczególne pokolenia i informatorów. Brak tu bowiem jakichkolwiek istotnych różnic. Rozpocznijmy od kontynuantów nosowości przed zwartą (wykres 8). W 97,8\% przypadków dochodzi tu do rozszczepienia z asymilacją. Tylko w jednym jedynym poświadczeniu $(2,2 \%)$ wymowa jest inna, zarejestrowałem tu mianowicie asynchroniczną realizację samogłoskową (['vuũtka] 'wędkę'). Wśród wymówień rozszczepionych 63,6\% to realizacje $\mathrm{z}$ całkowitym odnosowieniem segmentu samogłoskowego (np. ['knumpa] 'guzik', [dump] 'dąb', ['munkoũ] 'mąką', ['wuyka] 'łąka', ['wuntse] 'łące', ['vuntka] 'wędkę'). W 9,1\% przypadków zaobserwowałem nosowość częściową ([zuũ̃mp] 'ząb', [døõmp] 'dąb', ['wuũyka] 'łąkę', ['vuũntka] 'wędkę'). 27,3\% stanowią natomiast poświadczenia z nosowością całego segmentu samogłoskowego (['wũntse] 'łące', ['mũyka] 'mąkę', ['knũmpa] 'guzik', ['mũykum] 'mąką'). W trzech przypadkach nosowość rozprzestrzenia się na sąsiadujący glajd (['w̃ũyka] 'łąkę', ['w̃ũnka] 'ts.', [' wũntsc] 'łące'). Wystąpienie nosowości całego segmentu samogłoskowego jest wyraźnie skorelowane z miejscem artykulacji spółgłoski poprzedzającej pierwotną nosówkę. W 83,3\% takich przypadków mamy tu mianowicie spółgłoskę wargową (np. ['mũyka] 'mąkę' czy ['wũntse] 'łące'), a w pozostałych 16,7\% inną spółgłoskę (['knũmpa] 'guzik', ['tısõntsọ] 'tysiące'9). Dla pozostałych poświadczeń (włączając te o nosowości częściowej) odpowiedni udział spółgłosek wargowych i niewargowych wyniósł odpowiednio 28,1\% i 71,9\%. Jeszcze bardziej namacalna będzie ta zależność, gdy przedstawić ją z innej perspektywy. O ile nosowość całego segmentu wokalicznego jest typowa dla $8 \%$ przypadków, gdy pierwotna samogłoska nosowa stoi po spółgłosce niewargowej, to dla pozycji po wargowej liczba ta wynosi 50\%. Oczywiście nie może tu być mowy o przypadku (zagadnieniem tym zajmę się jeszcze niżej). Na koniec należy podkreślić, że w pozycji przed zwartą nie zarejestrowałem ani razu wymowy synchronicznej. U informatora M2 wymowa typu

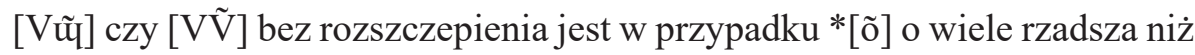
$\mathrm{u} *[\tilde{a}]$ (a właściwie wyjątkowa).

9 W drugim przypadku pierwotna nosówka stoi zresztą poza akcentem. 
Przejdźmy do pozycji przed szczelinowymi (wykres 9). W 85,2\% przypadków zaobserwowałem nosowość glajdową (np. [vuw̃x] 'węch', [vuũx] 'ts.', [vuw̃s] 'wąs', ['voũ̃s] 'ts.', ['vuw̃sọ] 'wąsy', ['kşuũusttr] 'książki', ['suũsṣ̣t] 'sąsiad', ['kuũ sọw] '(u)kąsił'), w 7,4\% - asynchroniczną samogłoskową (['suũsọt] 'sąsiad', [vuũx] 'węch'), w pozostałych 7,4\% - synchroniczną (['ksũfți] 'książki', ['sũsṣt] 'sąsiad'). Wśród realizacji glajdowych całkowite odnosowienie segmentu wokalicznego dotyczy $65,2 \%$ poświadczeń (por. przykłady powyżej), 8,7\% charakteryzuje się nosowością częściową ([vuũ̃̃x] 'węch', ['vuũ̃wsə] 'wąsy'), a w 26,1\% poświadczeń obserwujemy nosowość całego segmentu samogłoskowego (np. ['vũw̃ș̦] 'wąsy', ['vũ̃̃s š] 'ts.', ['sũ̃̃wș̣t] 'sąsiad'). Przed szczelinowymi zaobserwowano więc w nielicznych przypadkach nosowość synchroniczną. Wyraźnie dominuje tu jednak wymowa asynchroniczna. Sytuacja jest więc całkowicie odmienna niż ta opisywana dotychczas.

Ogólnie rzecz biorąc, w obu pozycjach absolutnie przeważa (97,2\%) nosowość asynchroniczna. Trudno tu właściwie stwierdzić, czy pojedyncze poświadczenia nosowości synchronicznej $(2,8 \%)$ są archaizmem czy też efektem wtórnej nazalizacji. Warto tu zwrócić uwagę, że tego typu wymowę zaobserwowałem tylko u przedstawicieli pokolenia młodszego. Zresztą przypadki całkowitej nosowości segmentu wokalicznego przy wymowie dyftongicznej stanowią u młodszych informatorów $40 \%$ poświadczeń, podczas gdy u starszych informatorów ta liczba wynosi $15 \%$. Przemawiać się to zdaje za hipotezą o wtórnej nosowości (patrz niżej). Innych, niewspomnianych dotąd typów nosowości (np. konsonantyzacji przed szczelinową, rozszczepienia bez asymilacji), opisywanych jako marginalne w dotychczasowych opracowaniach, nie zaobserwowałem ani razu.

Jeżeli chodzi o barwę, to artykulacje tylne wysokie [u, $v]$ stanowią 97,2\% wszystkich poświadczeń, przy czym większość z nich $(92,9 \%)$ to [u]. Tylko w 2,8\% zaobserwowałem barwę [0] ([domp'] 'dąb', ['tısõntsọ]). Glajd w większości przypadków (78,3\%) jest labializowany ([w̃]]), choć nierzadkie $(21,7 \%)$ są warianty płaskie ([ũ̃]). Nie stwierdziłem tu żadnych zasad dystrybucyjnych.

Na koniec należy zwrócić uwagę na jedną jeszcze kwestię. U śródgłosowego *[õ] nosowość segmentu samogłoskowego jest ogólnie w 21,5\% wszystkich poświadczeń (nie licząc całkowicie synchronicznych), udział takich realizacji jest więc spory. $U *[\tilde{a}]$ są to natomiast raczej wyjątki, stanowiące $1,6 \%$ 
wszystkich przykładów. Dodać tu należy, iż wargowość spółgłoski sąsiadującej z lewej strony $z$ *[õ] ma wyraźny wpływ na częstotliwość wymowy nosowej całego segmentu samogłoskowego w pozycji przed zwartą. Poza tym w przypadku $*[\tilde{o}]$ nie zanotowałem ani razu wymowy z denazalizacją, który to fakt niewątpliwie pozostaje w związku z zaokrągleniem wokalicznych kontynuantów *[õ] (zazwyczaj łącznie z glajdem) w przeciwieństwie do płaskich z zasady kontynuantów * [ã]. Wargowość jest więc bez wątpienia skorelowana z nosowością. Trudno jednak na podstawie zebranego materiału jednoznacznie określić, czy wargowość pozwala na zachowanie archaicznej nosowości, czy też ułatwia jej wtórne rozprzestrzenianie (dla opisu czysto synchronicznego należy oczywiście przyjąć drugą wersję). W kontekście wspomnianej powyżej różnicy międzypokoleniowej nie można drugiej hipotezy - jako wymagającej większej liczby przejść, więc bardziej złożonej - odrzucić wyłącznie w oparciu o zasadę ekonomii myślenia. Zresztą hipoteza ta jest bardziej złożona tylko i wyłącznie przy założeniu, że nosowość *[ã, õ] w kaszubszczyźnie była kiedykolwiek synchroniczna sensu stricto, co wcale nie jest oczywiste. Warto tu poza tym zauważyć, że nosowość *[õ] rozprzestrzeniać się może na wargowy glajd sąsiadujący lewostronnie (typ [' 'wũnka] 'łąkę'), co jest niewątpliwie zjawiskiem wtórnym. Częstego zachowania nosowości samogłoskowego kontynuantu *[õ] nie rozpatrywałbym ogólnie jako archaizmu.

\section{5. *[0̃] w wygłosie}

Przejdźmy do wygłosowego *[õ] (wykresy 10-11). Na wstępnie należy zauważyć, że na analizowany materiał składają się niemal wyłącznie realizacje nieakcentowane.

U informatorów starszych w 98,4\% przypadków doszło do rozszczepienia i wyodrębnienia się [m]. W trzech poświadczeniach tego typu (4,9\%) brak kontynuantu wokalicznego sensu stricto (['vjjalgm] 'rosną', ['rostsm] 'ts.', ['na Jm] 'naszą'), co jest skrajnym przykładem „niedbałej”' i zredukowanej wymowy końcówek poza akcentem ${ }^{10}$ (w obliczeniach dotyczących dalszych cech realizacji rozszczepionych przypadki te pomijam). 89,7\% przykładów z rozszczepieniem charakteryzuje się pełnym odnosowieniem segmentu

10 Oczywiście taka redukcja może zachodzić w takich końcówkach i w takim zakresie i stopniu, by nie utrudniać identyfikacji form. Wymowa typu ['rostsṃ] nadal pozwala całkowicie jednoznacznie określić, o jaką formę chodzi. 
wokalicznego (np. ['jędzum] 'jedzą', ['rostsom] 'rosną', ['pifom] 'piszą', ['mwetsnom] 'silną', ['zımum] 'zimą'). W jednym przypadku (1,7\%) zaobserwowałem nosowość częściową (['dobrữ̃̃m] 'dobrą'). W 8,6\% poświadczeń stwierdziłem zaś nosowość całego segmentu samogłoskowego ([sọ'nøvũ̃m] 'synową', ['mamũm] 'mamą', ['mșmũm] 'ts.', ['krəvũm] 'krową', [spjũm] 'śpią'). Zwrócić tu należy uwagę, iż znów w większości przypadków mamy tu do czynienia $\mathrm{z}$ wargowym kontekstem lewostronnym (w tym również z nosowym [m]). Do jedynego (1,7\% wszystkich wymówień) poświadczenia nosowości synchronicznej (['dəbrũ]) trudno się odnieść, zwłaszcza w kontekście pewnej niedbałości wymowy nieakcentowanych końcówek (o której wspomniałem już wyżej i na którą będę jeszcze zwracał uwagę) i prawostronnego sąsiedztwa spółgłoski szczelinowej. Normą jest więc u pokolenia starszego wymowa $\mathrm{z}$ wyodrębnionym [m]. Nosowość segmentu samogłoskowego w części poświadczeń można przy tym uznać za wtórną (uwarunkowaną nacechowanym kontekstem).

$\mathrm{W}$ materiale od młodszych informatorów wymówienia z rozszczepieniem i wyodrębnieniem [m] mają udział $84,6 \%$. W 70,9\% z nich samogłoska jest całkowicie odnosowiona (np. ['majụm] 'mają', ['mijęlom] 'mielą', ['jędzum] 'jedzą', ['krovum] 'krową', ['drogum] 'drogą', ['vjjalgum] 'dużą'). W 5,5\% obserwujemy nosowość częściową (['jędzuũ̃m] 'jedzą', [spjjuũm] 'śpią', ['droguũm] 'drogą'). W 23,6\% realizacji rozszczepionych nosowość obejmuje całą artykulację wokaliczną (np. ['pifũm] 'piszą', ['pij ũm] 'piszą', ['rostsũm] 'rosną', ['mwetsnũm] 'silną', ['matkũm] 'matką', ['dəbrũm] 'dobrą'). Brak tu korelacji z miejscem artykulacji spółgłoski sąsiadującej z lewa. Jak widzimy, zachowanie nosowości samogłoskowej jest tu wyraźnie częstsze niż w pokoleniu starszym. To samo dotyczy poświadczeń nosowości synchronicznej (np. [sũ] 'są', [sũ] 'ts.', ['dobrũ] 'dobrą'), które u młodszych informatorów stanowią 4,6\% wszystkich zarejestrowanych $\mathrm{u}$ nich form ${ }^{11}$. Poza tym nierzadko $(10,8 \%)$ pojawia się u osób młodszych wariant, niezarejestrowany przeze mnie u starszych informatorów. Chodzi o wymowę dyftongiczną. Najczęściej (85,7\%) połączona jest ona z pełną denazalizacją segmentu samogłoskowego (np. ['rostsuw̃] 'rosną',

11 Trzeba mieć jednak na uwadze, że również tutaj we wszystkich przypadkach bezpośrednio następuje spółgłoska szczelinowa w nagłosie kolejnego słowa. Poza tym większość poświadczeń takiej wymowy występuje w formie $s a$, stojącej poza akcentem, w bardzo słabej pozycji prozodycznej. 
['dobrow̃] 'dobrą', ['muykoũ] 'mąką'), rzadziej (14,3\%) rejestrowałem jego pełną nosowość (['pIfũw] 'piszą'). Poświadczenia nosowości dyftongicznej pochodzą głównie od informatora M1. W świetle wymowy pokolenia starszego niewykluczone jest, że mamy tu do czynienia z interferencją polszczyzny a przynajmniej ze zjawiskiem wtórnym. Realizacje dyftongiczne nie korelują z miejscem czy sposobem artykulacji następującej spółgłoski (zresztą znaczna część poświadczeń pochodzi z wygłosu absolutnego).

Ogólnie pełna nosowość segmentu samogłoskowego wystąpiła w 15,4\% poświadczeń fonetycznie złożonych (asynchronicznych) kontynuantów *[õ] w wygłosie. Nosowość synchroniczną zanotowałem zaś w 3,1\% wszystkich poświadczeń. Niezależnie od różnic międzypokoleniowych wymowa synchroniczna pozostaje więc rzadka. Niewykluczone zresztą, że jest ona zjawiskiem wtórnym, uwarunkowanym prawostronnym sąsiedztwem fonetycznym i brakiem akcentu. Tak czy inaczej, różnica w stosunku do starszych opisów jest niewątpliwa.

Podstawową barwą $(89,4 \%)$ wygłosowego *[õ] są [u, v] (por. przykłady powyżej). W 4,1\% przypadków (a więc nieco częściej niż pod akcen-

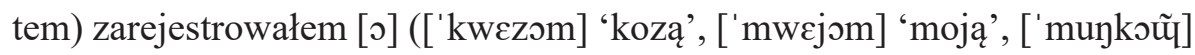
'mąką', [som] 'są', ['dugom] 'długą'). Aż 6,5\% to realizacje mocno zredukowane, z niezaokrągloną samogłoską typu [ə] (np. [səm] 'są', ['jidəm] 'idą', ['jçdzəm] 'jedzą', ['mwetsnəm] 'silną', ['pifəm] 'piszą'). Jest to zapewne ogniwo pośrednie pomiędzy wymową najbardziej reprezentatywną a realizacjami z całkowitą elizją samogłoski (patrz wyżej). Zresztą nawet [u, v] są w interesujących nas końcówkach często bardzo krótkie. Częstszą nosowość segmentu samogłoskowego niż pod akcentem można by w tym kontekście rozpatrywać jako rezultat „niedbałości” artykulacyjnej, promującej redukcje i asymilacje, a nie jako zjawisko archaiczne. W pewnej przynajmniej mierze mogłoby to dotyczyć również wymowy dyftongicznej (poświadczonej głównie u informatora o stosunkowo niedbałej wymowie, zwłaszcza sylab nieakcentowanych) i synchronicznej, jeżeli ta pierwsza nie byłaby rezultatem wpływu polszczyzny.

\section{6. [aN] i wyglosowe *[em]}

Jedenaście zarejestrowanych w przebadanym materiale realizacji słowa tam wystąpiło w formie [tam]. Nie zaobserwowałem identyfikacji wy- 
głosowej sekwencji tego słowa $\mathrm{z} *[\tilde{a}]$. Jeżeli chodzi ogólnie o połączenia *[aN], to w $78,8 \%$ wynotowanych poświadczeń barwa [a] nie ulega żadnym zmianom (['sama] 'sama', ['kamĩn] 'kamień', ['stsana] 'ściana'). W 21,2\% przypadków dochodzi do bardzo lekkiej labializacji i ewentualnie wzniesienia *[a] (np. ['tp̣mta] 'tamta', ['stsp̣nə] 'ściana', ['npma] 'nami'). Wartości te są ogólnie zgodne $\mathrm{z}$ danymi dla śródgłosowego *[ã].

Jeżeli chodzi o *[cm], to w trzech przypadkach na $49(6,1 \%)$ zanotowałem wymowę identyczną z *[ãa, czyli [a] bez śladów spółgłoski nosowej lub nazalizacji (['xwọpa] 'mężczyzną', ['xopa] 'ts.', ['pwıga] 'pługiem'). Poświadczenia tego rodzaju pojawiły się jednak tylko u jednego informatora (K1), u którego stanowią 21,4\% wszystkich jego wymówień i występują obok realizacji typu [em] w tych samych nawet słowach (np. ['pwıgem] 'pługiem'). Wśród poświadczeń typu [عm] w jednym przypadku (2,2\%) doszło do całkowitej elizji samogłoski (['tøasm] 'czasem'), w jednym zaobserwowałem nosowość częściową (['stəwes̃m] 'stołem'), a w pięciu $(11,1 \%)$ pełną (['kwદ̧nę̃m] 'koniem', ['xwọpãm] 'mężczyzną', ['t fasãm] 'czasem'). Są to liczby podobne jak np. w przypadku wygłosowego *[õ]. Stanowi to według mnie przesłankę za interpretacją częściowej lub pełnej nosowości segmentu wokalicznego w kontynuantach pierwotnych nosówek jako zjawiska wtórnego. Dodam jeszcze, że podobnie jak w przypadku wygłosowego *[õ] stwierdziłem tu znaczną liczbę realizacji ,niedbałych” (do 40\%), o silnej redukcji jakościowej samogłoski (np. ['pwっtə̣m] 'płotem', ['s3nə̦m] 'synem', ['pwestəm] 'postem').

\section{Podsumowanie}

Jeżeli ogólnie podliczyć poświadczenia w pozycjach, gdzie nosowość zachowuje się dzisiaj w ogóle (czyli wyłączając wygłosowe *[ã]), to realizacje synchroniczne stanowią tylko 1,9\% wszystkich wymówień (wykres 12). We wszystkich takich przypadkach pierwotna samogłoska nosowa - a konkretnie *[õ] - znajduje się przy tym przed spółgłoską szczelinową. Abstrahując od poświadczeń wymowy synchronicznej, nosowość całego segmentu samogłoskowego charakteryzuje 11,7\% przebadanych jednostek (a 95,5\% z nich to realizacje *[õ]). Pewne fakty przemawiają przy tym za tym, że zarówno nosowość synchroniczna, jak i pełna nosowość samogłoski przy wymowie asynchronicznej może być w dużej mierze, a nawet i całkowicie wtórna. No- 
sowość częściowa pojawiła się w 7,7\% poświadczeń. Tu wtórny charakter zjawiska jest chyba całkiem oczywisty. $Z$ fonologicznego punktu widzenia mamy tu do czynienia $z$ banalnymi faktami alofonicznymi, które nie wymagają żadnych dodatkowych objaśnień (każda samogłoska w sąsiedztwie spółgłoski nosowej może przyjmować nazalizację częściową lub całkowitą). Tylko 3,7\% wszystkich uwzględnionych tu poświadczeń to wymówienia całkowicie odnosowione. 94,4\% stanowią realizacje o jakimś rodzaju asynchronii, przy czym w ponad 2/3 z nich mamy do czynienia z wyodrębnioną spółgłoską nosową. Stan w przebadanym materiale różni się więc diametralnie od sytuacji przedstawionej w starszych opisach.

Dodać tu należy, że w przebadanym materiale nie sposób stwierdzić jakiejkolwiek leksykalizacji czy morfologizacji rozwoju nosówek.

Rozwój nosówek wyraźnie odcina gwarę strzepską od właściwych gwar zachodniocentralnokaszubskich (Jocz 2013), gdzie - poza wygłosowym *[õ] i pozycji przed $[\mathrm{k}, \mathrm{g}]$ - doszło do całkowitej i konsekwentnej denazalizacji. Na obszarze tym panuje wymowa [zup] ząb, ['zobs, 'zobc] zęby, ['юnka] ręka, ['muyka] mąka, [sum] sa (możliwa zresztą, choć ogólnie rzadka, jest wymowa ['roka], ['muka], na części obszaru występuje również fakultatywna wymowa [su]). Tendencja do denazalizacji jest stosunkowo nowa, a jej zwycięstwo dokonało się w przeciągu ostatnich kilkudziesięciu lat. Do gwary strzepskiej dotarła ona w bardzo ograniczonym stopniu, przejawia się ona bowiem ogólnie niezbyt często, tylko w pozycji przed szczelinowymi i wyłącznie u *[ã]. Zresztą nawet w tej pozycji kontynuanty nie są tu identyczne. Do gwary strzepskiej nie dotarły również zachodnio-centralno-kaszubskie innowacje związane z barwą. *[õ] nie przeszło tu konsekwentnie $\mathrm{w}[\mathrm{u}]$, ale zachowuje dość szeroki wachlarz barw, w tym bardziej otwartych (podobnie zresztą jak */o:/). *[ã] natomiast stosunkowo rzadko ulega zwężeniu z labializacją, przy czym brak w Strzepczu silnie labializowanych i niskich wariantów typu [p]. Zwrócić należy tu uwagę na całkowity właściwie brak wahań barwy *[ã] w wygłosie ${ }^{12}$. Ogniskiem tych powiązanych i bardzo silnych skądinąd tendencji była gwara sierakowsko-gowidlińska. Ich ekspansja w kie-

${ }^{12}$ Co ważne z punktu widzenia morfologii, np. biernik rzeczowników żeńskich na - $a$ nigdy nie odróżnia się tu fonetycznie od mianownika, inaczej niż we właściwych gwarach zachodniocentralnokaszubskich, gdzie oprócz wymowy tożsamej z *[a] istnieją jeszcze dwie w pełni fakultatywne realizacje [o, p], przy czym druga z nich jest unikalna dla tej formy. 
runku północnym (odmiennie np. niż we wschodnim) okazała się jednak bardzo ograniczona ${ }^{13}$. W konfrontacji z tendencją do konsonantyzacji nosowości, szerzącą się z północy, okazała się ona recesywna. Ogólnie zarówno pod względem barw ustnych, jak i kontynuantów nosowości gwara Strzepcza często aż do szczegółów (jak np. występowania wymowy dyftongicznej przed zwartymi głównie lub tylko w przypadku *[ã] czy o wiele częstszego zachowania nosowości segmentu samogłoskowego $\mathrm{u} *[\tilde{o}])$ zgodna jest z gwarą luzińsko-wejherowską (Jocz 2016a; 2016b). Oczywiście mamy tu też pewne istotne różnice. W interesującej nas gwarze nosowość *[ã $]$ w wygłosie nie jest zachowana w ogóle, podczas gdy w Luzinie możliwa jest również wymowa z częściową nosowością, jak również dyftongiczna oraz kon-

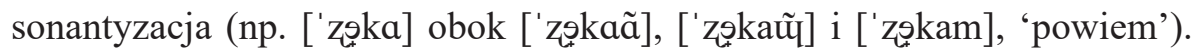
Poza tym nie zarejestrowałem w Strzepczu form z konsonantyzacją przed szczelinową (np. ['mijantso] 'mięso') czy z rozszczepieniem bez asymilacji (np. [pjjayts] 'pięć' albo ['jayzọk] 'język'), obecnych - choć bardzo rzadkich - w Luzinie ${ }^{14}$.

Na koniec przejdźmy do kwestii fonologicznych. Przyjmuję tu podejście uogólniające, umożliwiające uniwersalny opis dla wszystkich informatorów. Jak stwierdziłem powyżej już niejednokrotnie, kontynuanty dawnych nosówek są w pozycjach, gdzie nosowość zachowuje się w ogóle, niemal zawsze fonetycznie złożone. Przemawia to w oczywisty sposób za ich interpretacją jako połączeń dwufonemowych /aN/ i /oN/15 i odrzuceniem samogłosek nosowych w randze fonemów. Kwestią, którą należy tu rozwikłać, jest ustalenie fonemu, kryjącego się za symbolem /N/. W pierwszym rzędzie zwrócić trzeba uwagę, iż [n] i [n] wbrew dotychczasowym opisom (Topolińska 1967b: 115, 117) nie charakteryzują się w rzeczywistości dystrybucją komplementarną. Obie spółgłoski występują bowiem z zasady niewymiennie przed [k, g] (np. [sayk] 'sęk' wobec [bu'dọnk] 'dom'), przez co konieczne

13 Dodam, że wymowa w Mirachowie - przynajmniej w pokoleniu starszym - jest pośrednia pomiędzy sierakowsko-gowidlińską a tą typową dla gwary strzepskiej.

14 Zresztą rolę odgrywać tu może fakt, że informator, u którego zanotowałem te formy, jest wyraźnie starszy od moich starszych informatorów ze Strzepcza.

15 Pionowe wahania wymowy samogłoski w sekwencji /oN/ - niezależnie od ich genezy - należy uznać za uwarunkowane sąsiedztwem spółgłoski nosowej przy wyraźnej skłonności do nazalizacji regresywnej. Pozycja taka utrudnia precyzyjną percepcję poziomu samogłoski, co nierzadko jest źródłem rozchwiania lub wręcz zmian barwy ustnej samogłosek. 
jest przyjęcie fonemu odrębnego od $/ \mathrm{n} /(\mathrm{jak} \mathrm{i} / \mathrm{m}, \mathrm{n} /)$. Oznaczmy go roboczo symbolem $/ \mathrm{N} /$.

Rozpocznijmy od pozycji w śródgłosie przed zwartymi. Z punktu widzenia całości materiału nie możemy mówić o rozłożeniu pierwotnych nosówek na połączenia $/ \mathrm{Vm} /$ przed wargowymi i $/ \mathrm{Vn} /$ przed koronalnymi. Mamy tu bowiem - co prawda u jednego informatora i głównie w przypadku *[ã] bardzo dobrze poświadczoną wymowę glajdową lub (asynchroniczną) samogłoskową, która nigdy nie występuje w słowach jak ['sunt fi] 'sanki' czy ['bumtji] 'cukierki' z niewątpliwym /n, m/. Ze względu na miejsce artykulacji wspólne $\mathrm{z}$ [y] (i brak przesłanek fonologicznych przeciwko identyfikacji fonologicznej [y] z omawianymi tu glajdami w przebadanym materiale) można welarne glajdy [ũ̃, w̃] wraz z [y] opisać jako warianty /N/. Idąc dalej, za alofony tego fonemu uznać należy również nosowe segmenty samogłoskowe przy asynchronicznej nosowości samogłoskowej, które swobodnie wymieniają się w sekwencjach kontynuujących nosówki ze spółgłoskami i glajdami nosowymi. W tym ujęciu szeregi typu ['zambe], ['zaũys], ['zaãbe] ${ }^{16}$ 'zęby', ['pjanta], ['pjaũta], ['pjaãta] 'pięta', ['rayka], ['raũuka], ['raãka] 'ręka' są realizacjami uniwersalnych form głębokich /'zaNbN/, /'pjaNta/ i /raNka/. Oczywiście interpretacja taka ma oparcie tylko w wymowie starszego pokolenia. Dla samego pokolenia młodszego przyjąć należałoby tu odpowiednio połączenia $/ \mathrm{Vm} /, / \mathrm{Vn} / \mathrm{i} / \mathrm{VN} /$ i bardziej ograniczoną dystrybucję /N/. Poza tym takie ujęcie odnosi się głównie do *[ã], w przypadku $*[\tilde{o}]$ liczba odpowiednich poświadczeń jest absolutnie minimalna ${ }^{17}$. Cechą charakterystyczną /N/ (w ujęciu ogólnym) jest skłonność do asymilacji do następującej spółgłoski. W przypadku wymowy typu ['saũykuf] 'sęków' czy ['xaãntnદ̨] 'chętnie' sekwencję fonetyczną [ũy, ãn] można zinterpretować jako całość za realizację /N/ lub uznać [ũ, ã] za wtórny element alofoniczny samogłoski.

16 Nie wszystkie formy podawane w podsumowaniu jako ilustracja rozważań fonologicznych są zarejestrowane w przebadanym materiale. Niemniej jednak możliwość wszystkich takich realizacji wynika bezpośrednio z realnych poświadczeń.

17 Silniejsze zachowanie odrębności fonetycznej i fonologicznej kontynuantów *[ã] (w śródgłosie) jest typowe dla wszystkich chyba znanych mi gwar kaszubskich. Fakt ten w interesującej nas tu gwarze można by uznać za kolejną przesłankę, iż częstsze występowanie nosowości wokalicznej u *[õ] ma charakter wtórny. 
Dla pozycji przed szczelinowymi zastosowanie ma ta sama interpretacja. Odmienna jest tu jednak alofonia. Warianty konsonantyczne w tej pozycji nie występują. Podstawowymi alofonami są tu glajdy [ũ, w̃] Przed spółgłoskami miękkimi pojawia się tu natomiast fakultatywny wariant palatalny typu [j]. Oba te fakty wpisują się w ogólną tendencję do dopasowania /N/ pod względem miejsca i sposobu artykulacji do następującej samogłoski. W przypadku *[ã] występuje fakultatywny, odnosowiony alofon /N/. O złożonej strukturze fonologicznej w przypadkach jak [gaes] 'gęś' świadczy łączna długość artykulacji samogłoskowej wraz z jej asynchronicznym fonetycznie charakterem ${ }^{18}$ oraz swobodne występowanie obok wymowy typu [gaũs] nie tylko w ramach gwary, ale również pojedynczego idiolektu. Wymowa synchroniczna *[õ] przed szczelinowymi jest na tyle rzadka, że nie może być poważnym argumentem za przyjęciem samogłoski nosowej w randze fonemu. Mamy tu do czynienia $\mathrm{z}$ realizacją dwóch jednostek głębokich jako jednego segmentu powierzchniowego w bardzo sprzyjających do tego warunkach fonetycznych.

Jeżeli chodzi o wygłos, to w przypadku *[ã] brak w przebadanym materiale jakichkolwiek realnych przesłanek do uznania jego odrębności fonologicznej od *[a]. Wygłosowe *[õ] bez wątpienia jest realizacją sekwencji dwufonemowej: również w tej pozycji udział nosowości synchronicznej jest bardzo niski, a odpowiednie poświadczenia ograniczone do nacechowanego kontekstu. Dla materiału pochodzącego od starszych informatorów rozpatrywanego oddzielnie przyjąć należałoby tu strukturę / $\mathrm{Vm} /$. Jako że u informatorów młodszych pojawia się nierzadko wymowa dyftongiczna, to - abstrahując od jej genezy - dla gwary jako całości widzieć tu trzeba strukturę z wygłosowym /N/ ze swobodnymi alofonami [ü, $\tilde{w}, \mathrm{~m}$ ] oraz synchronicznym wariantem reprezentującym całą sekwencję. Zaznaczyć tu należy, że słowa jak sóm 'sam' wymawiane są zawsze z zachowaniem wygłosowego [m].

Wahania w wymowie wygłosowego *-em rozpatrywać najlepiej chyba na płaszczyźnie morfologicznej jako wariantywność końcówki narzędnika. Interpretacja na poziomie fonologicznym (np. uznanie [a] za swobodny wariant sekwencji / $\mathrm{\varepsilon m} / \mathrm{w}$ wygłosie) byłaby mało przekonująca.

18 Sytuacja jest tu więc nieco odmienna niż we właściwych gwarach zachodniocentralnokaszubskich, z której to przyczyny dla podobnego zjawiska przyjąłem zerowy alofon /y/, a odmienną jakość samogłoski uznałem za zjawisko alofoniczne w pozycji przed wszystkimi spółgłoskami nosowymi. 
Ostatnim zagadnieniem jest przypisanie alofonu podstawowego fonemowi oznaczonemu roboczo jako /N/ i ustalenie konkretnego, optymalnego symbolu transkrypcji. Tam, gdzie /N/ odróżnia się fonetycznie od innych spółgłosek nosowych, ma ono artykulację tylną, welarną. Możemy więc ograniczyć rozważania do wyboru pomiędzy /y/a /ũ, w̃/. Dla gwary luzińskiej, charakteryzującej się ogólnie podobnym rozwojem nosówek, przyjąłem /y/. Gwara strzepska nie zna jednak wymowy typu ['jayzọk] 'język', łatwej do objaśnienia przy przyjęciu /y/ jako punktu wyjściowego, a dość trudnej do wyprowadzenia $\mathrm{z} / \tilde{\mathrm{u}}, \tilde{\mathrm{w}} /$. Poza tym wymowę glajdową przed spółgłoskami zwartymi notowałem tam rzadziej niż w interesującej nas tu gwarze. Fonem (i symbol)/y/ przyjąłem też w opisie właściwych gwar centralnokaszubskich. Część tych gwar nie zna jednak w ogóle [ũ, w̃] (przy regularnym i w przypadku realizacji niezerowej obligatoryjnym [y] przed $[\mathrm{k}, \mathrm{g}]$ ), a sam opis jest w pewnym zakresie na tyle abstrakcyjny, że dyskusja o wyższości jednego rozwiązania i oznaczenia nad drugim traci w dużej mierze sens. Dla gwary strzepskiej najbardziej adekwatne wydaje się przyjęcie tu jako struktury głębokiej glajdu nosowego. Po pierwsze w przebadanym

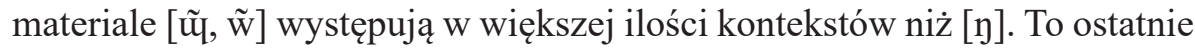
ograniczone jest do pozycji przed [k, g], podczas gdy glajdy występują fakultatywnie przed wszystkimi zwartymi i w wygłosie oraz regularnie przed wszystkimi szczelinowymi. Po drugie to z glajdu najprościej wyprowadzać konkretne warianty fonetyczne. Stanowi on przy tym ogniwo, w najbardziej przekonujący sposób łączące wszystkie rodzaje realizacji omawianego fonemu, zarówno konkurujące w jednej i tej samej pozycji, jak i uwarunkowane kontekstem. Np. przy założeniu fonologicznego glajdu generowanie form powierzchniowych jak ['zaũbs, 'raũ ka] nie wymaga żadnych dodatkowych reguł, inaczej niż przy przyjęciu /y/. Formy typu ['zambe, rayka] reguły wymagają, ale ona i tak byłaby potrzebna, a ostatecznie mamy tu jedną regułę zamiast dwóch. Glajd fonologiczny stanowi też najbardziej realny fonetycznie pomost pomiędzy realizacjami skonsonantyzowanymi (['zambe]) a asynchronicznymi samogłoskowymi (['zaãbe]) przed zwartymi czy też pomiędzy skonsonantyzowanymi przed zwartymi (['zambe]) a odnosowionymi przed szczelinowymi (['gaese]). Wszędzie zresztą glajd może wystąpić jako taki również materialnie (['zaũube, 'gaũusc]). Większość realizacji powierzchniowych - jeśli nie wszystkie - da się przy tym ująć przy założeniu fonologicznego glajdu pod ogólną zasadę (fakultatywnej) asymilacji 
(czy - ujmując mniej kategorycznie - zbliżenia) realizacji omawianego fonemu pod względem miejsca i sposobu artykulacji do następującej spółgło-

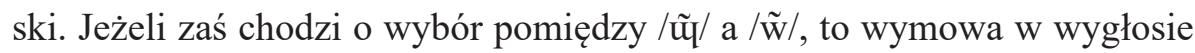
absolutnym, gdzie najczęstszym alofonem jest [m] (a więc spółgłoska wargowa), przemawia za symbolem $/ \tilde{\mathrm{w}} /{ }^{19}$. Ogólnie rzecz biorąc, jest to więc interpretacja bliska tej współcześnie przyjmowanej dla polszczyzny ogólnej (por. Dukiewicz i Sawicka 1995: 131-132).

Kontynuanty samogłosek nosowych w gwarze strzepskiej - jeśli brać dotychczasowe opisy za dobrą monetę - uległy w ciągu ostatnich kilkudziesięciu lat znacznym zmianom zarówno pod względem fonetycznym, jak i fonologicznym. Zmiany te pozwalają nam obserwować na żywo procesy, przebieg których możemy dla innych języków i epok tylko rekonstruować. Pełen opis niektórych zjawisk wymaga badań akustycznych oraz artykulacyjnych, które powinny stać się podstawą odrębnego studium.

\section{Wykresy}

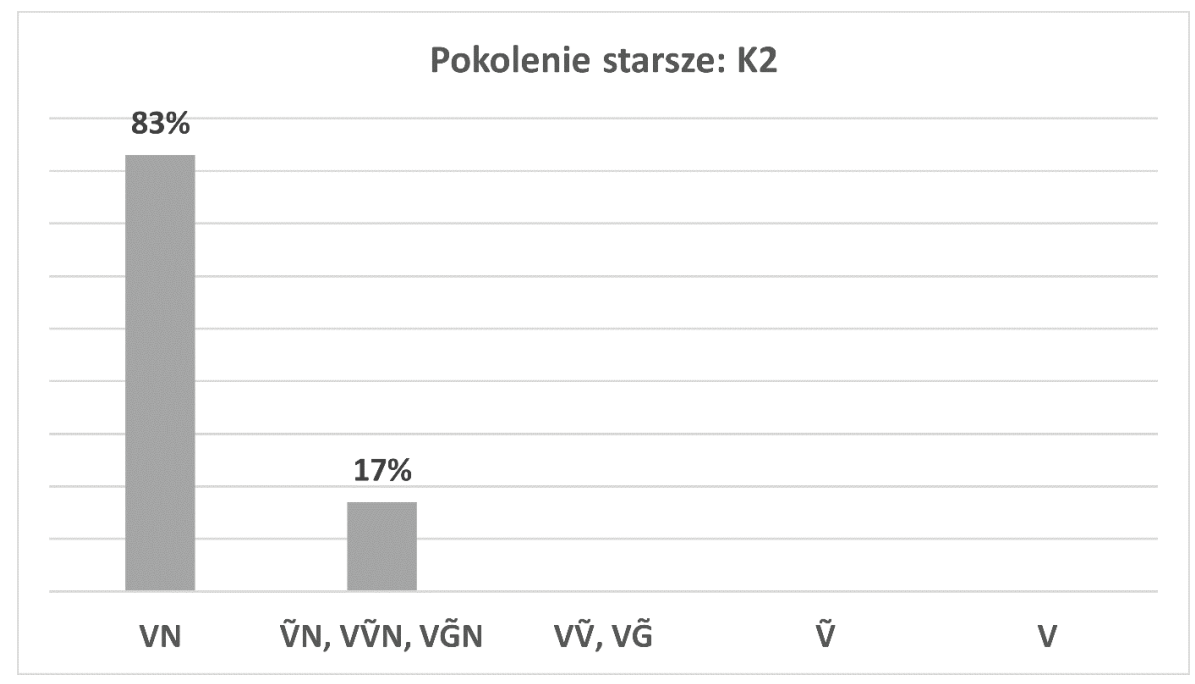

Rysunek 1. Wymowa *[ã] w śródgłosie przed zwartymi: pokolenie starsze, informator K2 nej IPA.

19 Takie oznaczenie odpowiada też lepiej ogólnym zasadom transkrypcji fonologicz- 
Pokolenie starsze: M2

\begin{tabular}{|c|c|c|c|c|}
\hline \multicolumn{5}{|c|}{$68 \%$} \\
\hline & & & & \\
\hline & & & & \\
\hline & $21 \%$ & & & \\
\hline $10 \%$ & & & & \\
\hline VN & $\tilde{V} N, V \tilde{V} N, V \tilde{G} N$ & 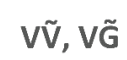 & $\tilde{\mathbf{v}}$ & V \\
\hline
\end{tabular}

Rysunek 2. Wymowa *[ã] w śródgłosie przed zwartymi: pokolenie starsze, informator M2

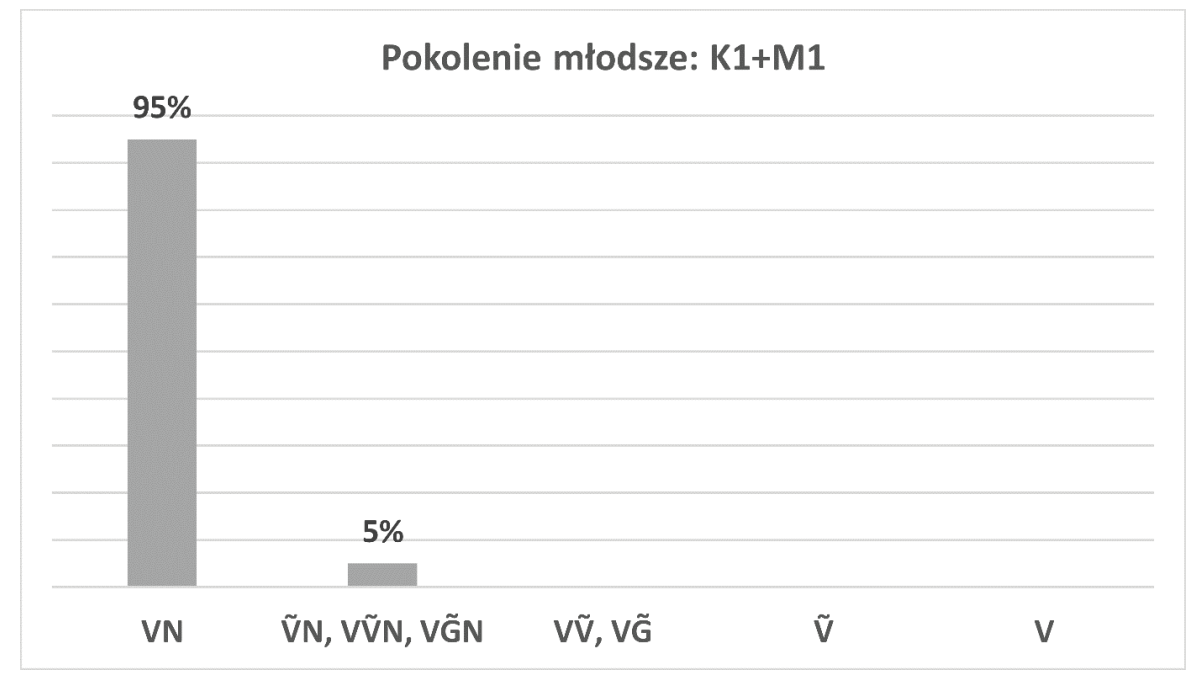

Rysunek 3. Wymowa *[ã] w śródgłosie przed zwartymi: pokolenie młodsze, informatorzy K1 i M1 
Pokolenie starsze: $\mathrm{K} 2+\mathrm{M} 2$

\section{$92 \%$}

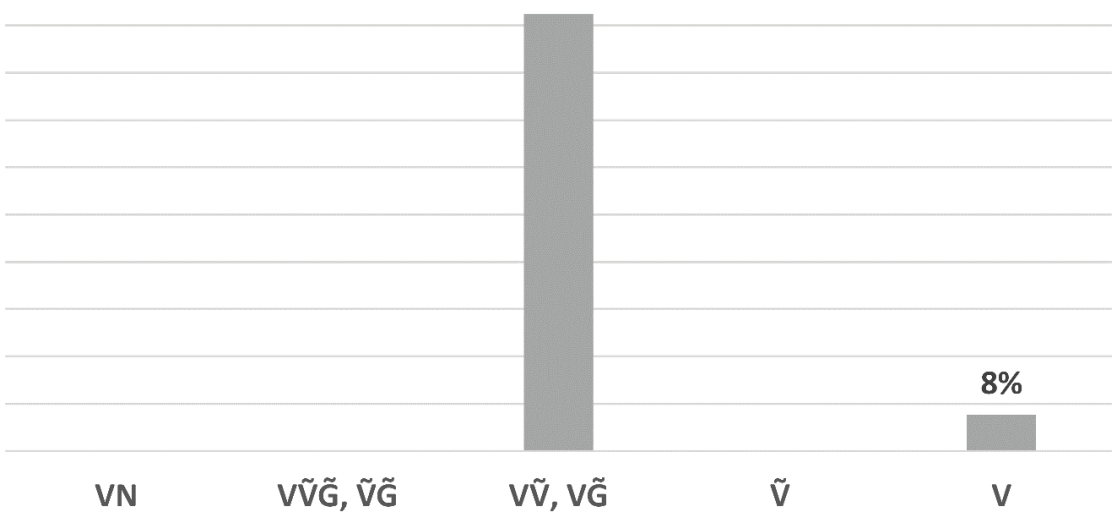

Rysunek 4. Wymowa *[ã] w śródgłosie przed szczelinowymi: pokolenie starsze, informatorzy K2 i M2

Pokolenie młodsze: K1

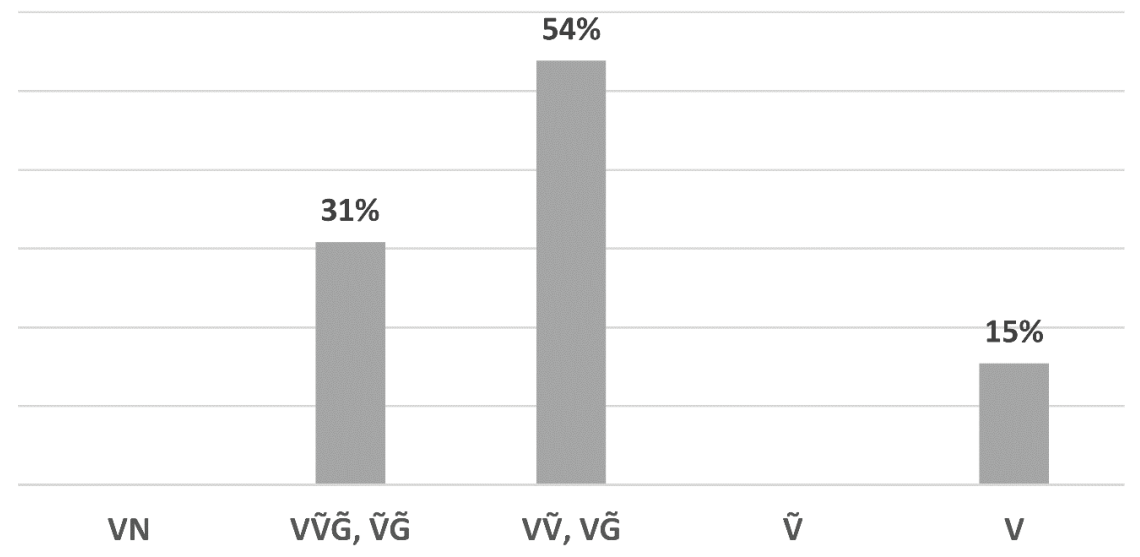

Rysunek 5. Wymowa *[ã] w śródgłosie przed szczelinowymi: pokolenie młodsze, informator K1 


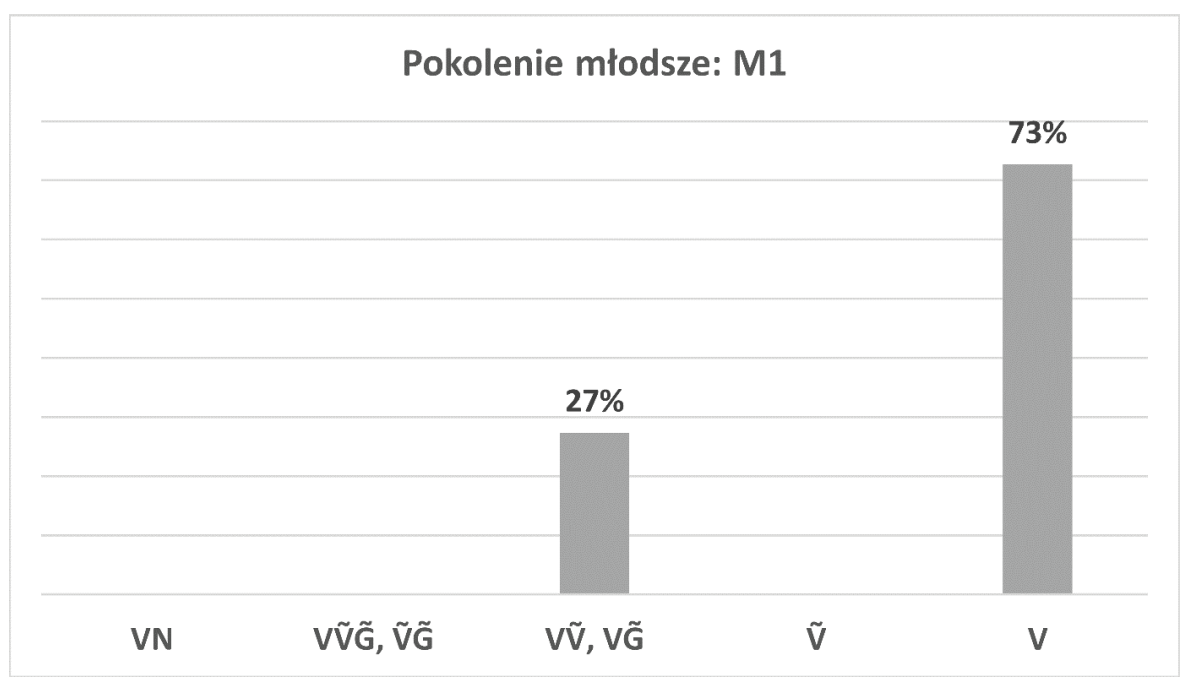

Rysunek 6. Wymowa *[ã] w śródgłosie przed szczelinowymi: pokolenie młodsze, informator M1

Pokolenie młodsze i starsze: $\mathrm{K} 1+\mathrm{M} 1+\mathrm{K} 2+\mathrm{M} 2$

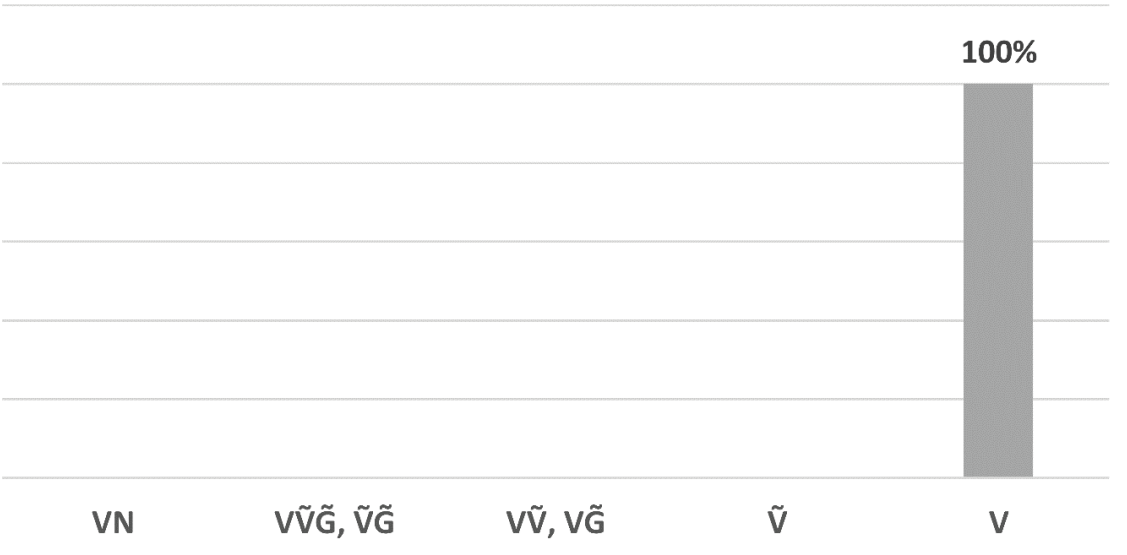

Rysunek 7. Wymowa *[ã ] w wygłosie: wszyscy informatorzy 
Pokolenie młodsze i starsze: $\mathrm{K} 1+\mathrm{M} 1+\mathrm{K} 2+\mathrm{M} 2$

$62 \%$

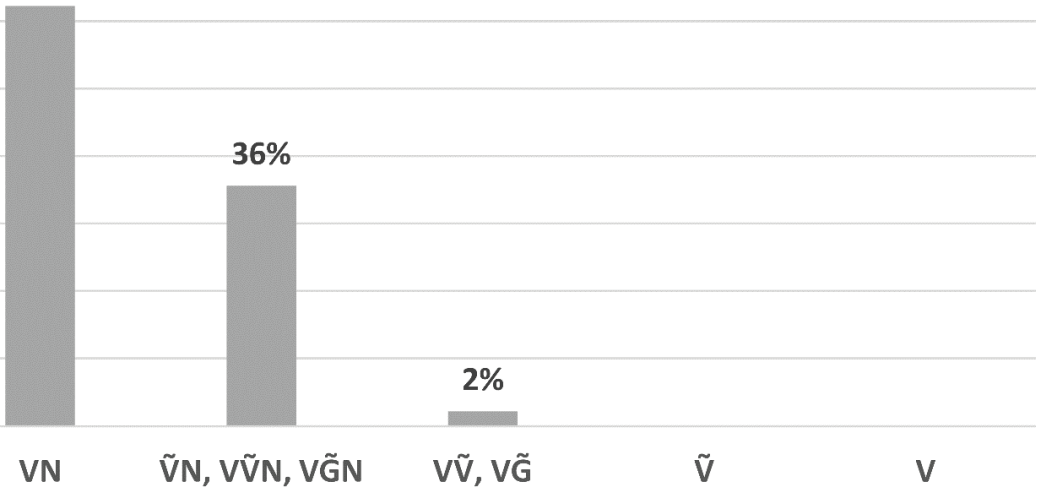

Rysunek 8. Wymowa *[õ] w śródgłosie przed zwartymi: wszyscy informatorzy

Pokolenie młodsze i starsze: $\mathrm{K} 1+\mathrm{M} 1+\mathrm{K} 2+\mathrm{M} 2$

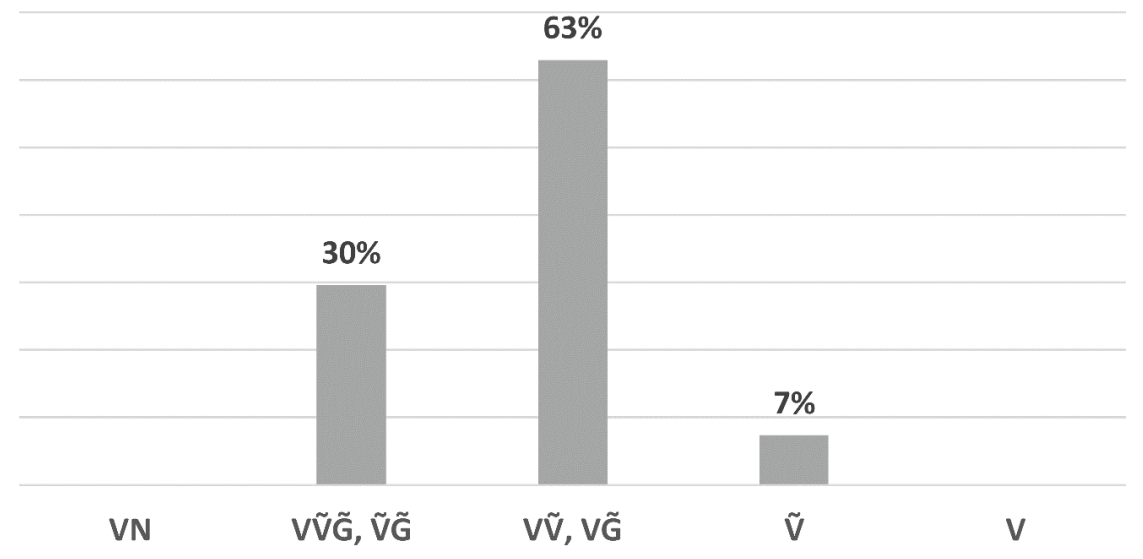

Rysunek 9. Wymowa *[õ] w śródgłosie przed szczelinowymi: wszyscy informatorzy 
Pokolenie starsze: $\mathrm{K} 2+\mathrm{M} 2$

\section{$88 \%$}

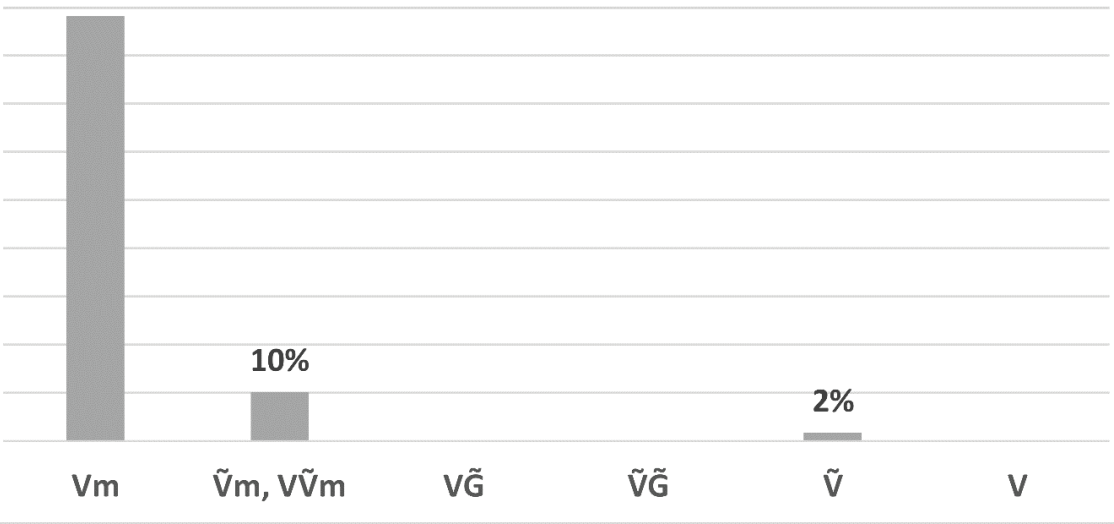

Rysunek 10. Wymowa *[õ] w wygłosie:

pokolenie starsze, informatorzy K2 i M2

\section{Pokolenie młodsze: K1+M1}

\section{$60 \%$}

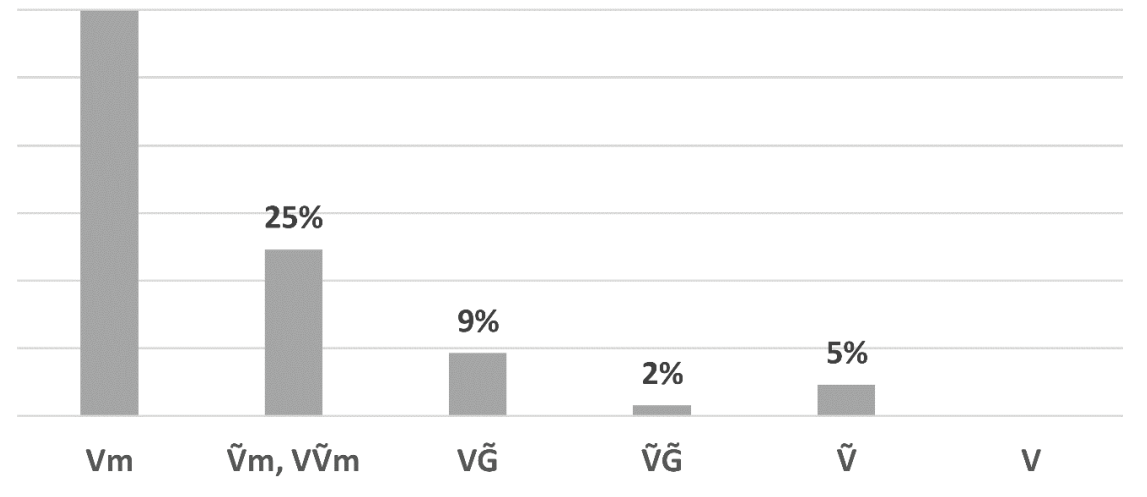

Rysunek 11. Wymowa *[õ] w wygłosie: pokolenie młodsze, informatorzy K1 i M1 


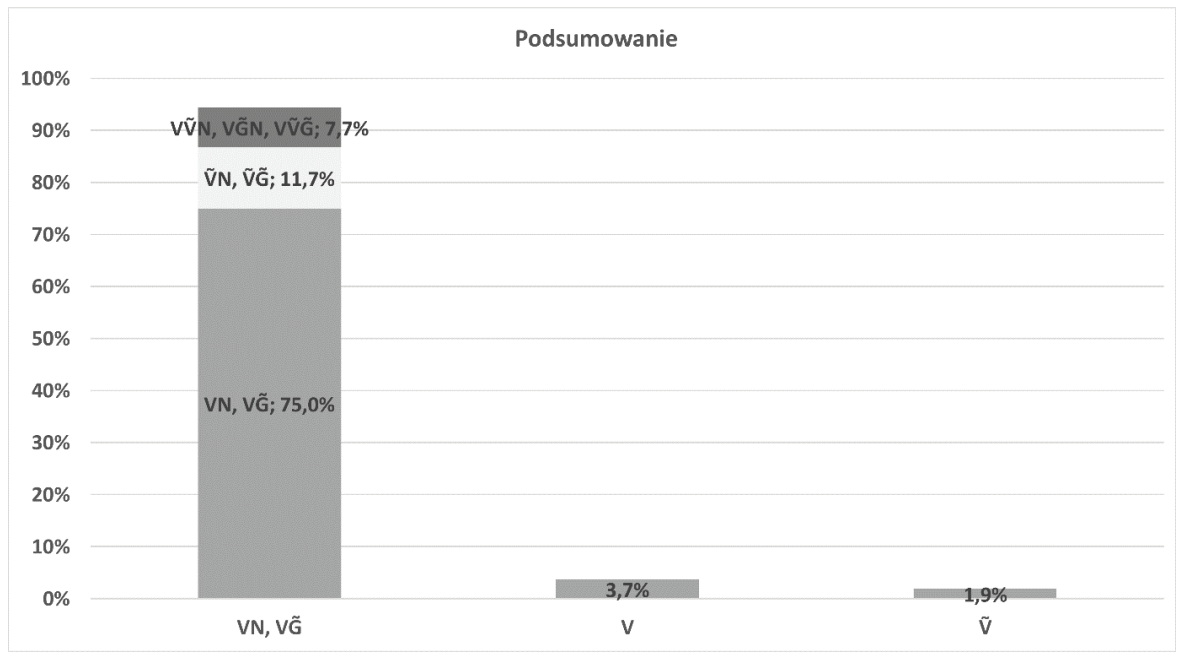

Rysunek 12. Kontynuanty nosowości: podsumowanie ogólne

\section{Bibliografia}

AJK: Atlas językowy kaszubszczyzny i dialektów sąsiednich I-XV, 1964-1978, Zespół Zakładu Słowianoznawstwa PAN (red.), Wrocław-Warszawa-Kraków: Zakład Narodowy im. Ossolińskich.

BisKuPSKi L., 1883, Die Sprache der Brodnitzer Kaschuben im Kreise Karthaus (West-Preussen), H. 1: Lautlehre-Abteilung A, Leipzig: Breithof \& Härtel.

Dukiewicz L., SAwicka I., 1995, Gramatyka współczesnego języka polskiego. Fonetyka i fonologia, Kraków: Wydawnictwo Instytutu Języka Polskiego PAN.

Jocz L., 2013, System samogłoskowy współczesnych gwar centralnokaszubskich, Szczecin: Volumina.

Jocz L., 2014, System spółgłoskowy współczesnych gwar centralnokaszubskich, Szczecin: Volumina.

Jocz L., 2015a, System samogłoskowy współczesnych gwar zaborskich, Rocznik Slawistyczny 64, s. 27-48.

Jocz L., 2015b, System samogłoskowy współczesnej kaszubszczyzny północno-zachodniej, Slavia Occidentalis 72/1, s. 39-63.

Jocz L., 2016a, System samogłoskowy gwary luzińskiej, Polonica 36, w druku.

Jocz L., 2016b, Miejsce gwary luzińskiej wśród gwar kaszubskich w świetle faktów fonetycznych i fonologicznych, w druku. 
ŚCIEBORAA., 1973, Wymowa samogłoseknosowych w gwarach kaszubskich, Wrocław-Warszawa-Kraków-Gdańsk: Zakład Narodowy im. Ossolińskich.

TopolińsKa Z., 1967a, Teksty gwarowe południowokaszubskie z komentarzem fonologicznym, Studia z Filologii Polskiej i Stowiańskiej 6, s. 115-141.

TopolińsKa Z., 1967b, Teksty gwarowe centralnokaszubskie z komentarzem fonologicznym, Studia z Filologii Polskiej i Stowiańskiej 7, s. 88-125.

Topolı́́sKa Z., 1969, Teksty gwarowe północnokaszubskie z komentarzem fonologicznym, Studia z Filologii Polskiej i Stowiańskiej 8, s. 67-93.

Гильфердинг А., 1862, Остатки Славянъ на южномъ берегу Балтійскаго моря, Петерсбург: Имераторское Русское Географическое Общество.

\section{The Development of the Nasal Vowels in the Kashubian Dialect of Strzepcz}

(summary)

The paper is devoted to the development of the former nasal vowels in the Kashubian dialect of Strzepcz. Taking into consideration modern analyses of their pronunciation in other Kashubian dialects, one can assume that older descriptions are highly outdated. The paper is based on the auditory analysis of over 450 realisations of the original nasal vowels in various contexts with a support of the visual analyses of spectrograms and auxiliary acoustic measurements. There were four informants: two representing the middle generation (a man and a woman) and two (a man and a woman) from the older generation.

A synchronous nasality occurred in only $1,9 \%$ of realisations (without taking account of $*[\tilde{a}]$ at the end of the word where it is denasalized without exception) and only in the case of $*[\tilde{o}]$ in the front of fricative consonants. In $3,7 \%$ of realizations a full denasalisation was observed. In $94,4 \%$ of cases occurred an asynchronous nasality with a vowel and following nasal consonant or a glide. The vocalic (syllabic) segment is in over $80 \%$ of asynchronous realisations fully denasalised. The observed situation is diametrically different from those presented in the older descriptions. From the phonological point of view on should analyse the original nasal vowels as sequences of $/ \mathrm{V} /$ and underlying glide $/ \tilde{\mathrm{w}} /$. 